\title{
Pulpotomy vs. pulpectomy techniques, indications and complications
}

\author{
Seraj Al Baik ${ }^{1 *}$, Abbas Al Mkenah ${ }^{2}$, Abdulmomen Khan ${ }^{3}$, Abdullah Alkhalifah ${ }^{4}$, \\ Ahmed Al Makinah ${ }^{5}$, Haitham Alquraini ${ }^{5}$, Ali Al Khars ${ }^{6}$, Alanoud Almakinah ${ }^{7}$, \\ Doaa Almakinah $^{7}$, Alaa Almalki ${ }^{7}$
}

\begin{abstract}
Department of Dentistry, ${ }^{1}$ Salwa General Hospital, Salwa, ${ }^{4}$ Alrass Dental Clinics, Ar Rass, Saudi Arabia
${ }^{2}$ Department of Oral and Maxillofacial Surgery, King Fahad Hospital, Al Hofuf, Saudi Arabia

College of Dentistry, ${ }^{3}$ Batterjee Medical College, Jeddah, Saudi Arabia; ${ }^{6}$ Riyadh Elm University, Riyadh, Saudi

Arabia; ${ }^{7}$ Jordan University of Science and Technology, Irbid, Jordan

${ }^{5}$ College of Dentistry, Alfarabi Colleges, Riyadh, Saudi Arabia
\end{abstract}

Received: 27 September 2018

Accepted: 13 October 2018

\author{
*Correspondence: \\ Dr. Seraj Al Baik*, \\ E-mail: albaik27@gmail.com
}

Copyright: () the author(s), publisher and licensee Medip Academy. This is an open-access article distributed under the terms of the Creative Commons Attribution Non-Commercial License, which permits unrestricted non-commercial use, distribution, and reproduction in any medium, provided the original work is properly cited.

\begin{abstract}
Several pulp therapies were developed to maintain the health and integrity of the teeth pulps because of their necessity for physiological growth of healthy permanent teeth with a long-term preserved function. Pulp therapies aims mainly at protecting the teeth that were affected by caries, infection, or trauma. Pulpotomy and pulpectomy are the most common utilized pulp therapies, and the choice between them depends on several factors, for instance, the vitality of the existing pulp, the portion of the pulp involved (e.g. coronal versus radicular portions), the presence or absence of reversible/irreversible pulpitis, the presence or absence of a necrotic pulp, the state of surrounding bones and soft tissues, and the presence or absence of infection, abscesses, fistulae, or underlying cysts. Basically, pulpotomy is usually therapy of option in patients with vital pulps, whilst pulpectomy is preferred in cases with non-vital teeth pulps. This article will review and summarize the main differences between pulpotomy and pulpectomy particularly regarding their definition, indications, techniques, and complications.
\end{abstract}

Keywords: Complications, Indications, Pulp therapy, Pulpectomy, Pulpotomy, Techniques

\section{INTRODUCTION}

Teeth pulps are necessary for healthy physiological apexogenesis particularly in early-formed permanent teeth with immature roots. ${ }^{1}$ Therefore, several pulp therapies were developed to maintain the health and integrity of the teeth pulps to protect teeth that were affected by caries, infection, or trauma. ${ }^{2}$ An integral tooth pulp allows a long-term maintenance of a healthy permanent tooth with an adequate crown-root ratio, and subsequently allows preservation of adequate function. ${ }^{2}$ The most common pulp therapies developed to maintain the dental pulp integrity are pulpotomy and pulpectomy.
Choice of therapy should be tailored to each particular patient according to multiple factors such as the vitality of the existing pulp, the portion of the pulp involved (e.g. coronal versus radicular portions), the presence or absence of reversible/irreversible pulpitis, the presence or absence of a necrotic pulp, the state of surrounding bones and soft tissues, and the presence or absence of infection, abscesses, fistulae, or underlying cysts. ${ }^{3-6}$

This article aims at reviewing and summarizing the main differences between pulpotomy and pulpectomy particularly regarding their definition, indications, techniques, and complications. 


\section{PULPECTOMY VERSUS PULPOTOMY}

Pulpotomy is the procedure of removal of the coronal part of the dental pulp followed by application of a medicament. ${ }^{7}$ Pulpectomy, on the other hand, refers to the procedure of removing the whole contents of the chamber pulp and its root canal. ${ }^{8}$ In pulpectomy, the root canals are then filled with specific substances that to protect against recurrent infection. Pulpectomy can be total, where the whole pulp is removed until the apical foramen, or partial, where a pulp with an open apex or an incompletely formed root is formed. ${ }^{9}$ The main objectives of pulpectomy are to clean the root canals, obturate them, protect them from potential infection, and subsequently promoting healthy development of physiological roots.

Each of the two procedures has a certain technique, specific indications, and potential outcomes. The next section will summarize each procedure and Table 1 demonstrates the main differences between them.

Table 1: Summary of the differences between barium and air reduction techniques.

\begin{tabular}{|c|c|c|}
\hline & Pulpotomy & Pulpectomy \\
\hline \multicolumn{3}{|l|}{ Technique } \\
\hline & $\begin{array}{l}\text { Removal of coronal part of dental pulp } \\
\text { followed by application of a medicament }\end{array}$ & $\begin{array}{l}\text { Removing the whole contents of the chamber } \\
\text { pulp and its root canal }\end{array}$ \\
\hline Indications & $\begin{array}{ll}\text { - } & \text { Vital teeth } \\
\text { - } & \text { Healthy periodontium } \\
\text { - } & \text { Only coronal involvement } \\
\text { - } & \text { Contraindicated extraction } \\
\text { - } & \text { Absence of infection/abscess } \\
\text { - } & \text { Absence of fistula } \\
\text { - } & \text { Absence of spontaneous pain } \\
\text { - } & \text { Absence of involvement of pulp floor } \\
- & \text { Absence of inter-radicular bone loss }\end{array}$ & $\begin{array}{ll}\text { - } & \text { Non-vital teeth } \\
\text { - } & \text { Furcation } \\
\text { - } & \text { Coronal and radicular involvement } \\
\text { - } & \text { Dental abscess } \\
\text { - } & \text { Irreversible pulpitis } \\
\text { - } & \text { Primary teeth with necrotic pulp } \\
\text { - } & \text { Pulpless primary teeth with need to arch } \\
& \text { maintenance } \\
\text { - } & \text { Absence of underlying cysts }\end{array}$ \\
\hline Complications & $\begin{array}{ll}\text { - } & \text { Anaesthesia complications } \\
\text { - } & \text { Tooth fracture } \\
\text { - } & \text { Tooth discoloration } \\
\text { - } & \text { Persistent pain }\end{array}$ & $\begin{array}{ll}- & \text { Anaesthesia adverse effects } \\
- & \text { Tooth discoloration } \\
- & \text { Local infection } \\
- & \text { Pain } \\
\text { - } & \text { Local bleeding } \\
- & \text { Tooth fracture } \\
- & \text { Tooth loss }\end{array}$ \\
\hline
\end{tabular}

\section{PULPOTOMY TECHNIQUES, INDICATIONS, COMPLICATIONS}

To perform pulpotomy, a local anaesthetic is initially injected at the site of procedure and a dental rubber dam is applied to isolate the surgical field from the rest of the oral cavity to minimize bacterial contamination. ${ }^{4}$ The first step of the procedure is to remove the visible dental caries until the pulp chamber is accessed. ${ }^{10} \mathrm{~A}$ cotton piece is then inserted to stop any potential bleeding. Once the dentist feels a dip, he begins side to side movement to extent the dental roof. ${ }^{11}$ Getting the pulp clearly accessible, the dentist removes its coronal pulp using an excavator or a round bar. After that, the dental medicament is inserted. ${ }^{12}$ The most common used dental medicaments for this procedure are ferric sulphate or formocresol. ${ }^{3}$ At this moment, the cotton is removed, and the dentist ensures there is no bleeding points. Because pulpotomy implies manipulation of the deep part of the dental pulp, acute or chronic pulpitis is a potential consequence and, therefore, zinc oxide eugenol (ZOE) should be applied to the dental chamber to provide a temporary sedating effect. ${ }^{13}$ Finally, a stainless-steel crown is inserted, and coronal restoration is placed. ${ }^{5,14,15}$
The main indication for pulpotomy is the existence of proximal extensive dental caries that involve the marginal ridge particularly when extraction is contraindicated.,10 Pulpotomy is the procedure of choice when the dentitions are vital with a healthy periodontium, and when there is no local infection or abscesses. ${ }^{4,5,16,17}$ Pulpotomy is not preferred in case when a dental fistula or episodes of spontaneous dental pain exists. ${ }^{4,5}$ Additionally, it is contraindicated in cases where the dental caries extends to involve the radicular portion of the pulp or when the caries penetrates deeply to the pulp chamber floor. ${ }^{7,18}$ Pulpotomy is also contradicted in cases of inter-radicular bone loss. 5

Complications following pulpotomy are usually mild. Pain is not uncommon, due to inflammation of the surrounding soft tissue during procedural manipulation, however, it is usually mild and self-resolving. Severe or persistent pain, on the other sign, is an eminent symptom that indicated a necessity for further dental intervention or tooth extraction. After pulpotomy, teeth become fragile and they are very prone to fracture. This risk of teeth fracture can be minimized by inserting a strong filling or applying a durable crown. Teeth discoloration is 
also an evitable complication of pulpotomy, and the complications of anaesthesia are not uncommon. ${ }^{7}$

\section{PULPECTOMY TECHNIQUES, INDICATIONS, COMPLICATIONS}

Prior to a pulpectomy procedure, dentists should be aware of the primary anatomy of the root canals of the teeth to be operated, and to meticulously evaluate the proximity of the succedaneus dentitions. ${ }^{19,20}$ Getting started, a local anesthetic agent $\mathrm{s}$ to be injected and a rubber dam is to be applied to prevent transmission of bacteria from the rest of the oral cavity. The caries is to be then removed until the exposure area can be identified. $^{21,22}$ Thereafter, a fissure bar is utilized to remove the pulp chamber roof. An excavator is then used to remove both the coronal and radicular portions of the dental pulp, respectively. Having the roof, radicular portion, and cranial portion all removed, the root canal is cleansed using an $\mathrm{H}$-files. ${ }^{21,22}$ Saline is then irrigated into the root canal to ensure cleansing, and formocresol is subsequently placed. After that, zinc oxide is applied to prevent infection. Obturation of the canal roots is the supposed next step and can be performed via various techniques such as lentulo spiral technique, incremental fill technique, and endodontic pressure syringe technique. ${ }^{23}$ A ZOE cement is then filled into the root canal and a stainless-steel crown is inserted to restore the operated tooth. ${ }^{21,22}$

In contrary to pulpotomy, pulpectomy is indicated in cases of extensive caries involving both the coronal as well as the radicular portions of the teeth leading to irreversible pulpitis. ${ }^{24}$ It is the operation of choice in cases of dental abscesses, furcation, or non-vital teeth. It is also indicated in case of primary molars or incisors caries that necessitates application of a maintenance arch ${ }^{25,26}$ Pulpectomy can also be used in cases of primary dentitions with necrotic pulps and pulp less primary dentitions particularly when a space maintainer is indicated. ${ }^{911}$ However, it is not suitable for teeth with underlying cystic lesions (e.g. dentigerous cysts or follicular cysts), dentitions with non-restorable crowns, or teeth with extensive resorption internally (at least one third of the root). ${ }^{4,17}$ Pulpectomy is also contraindicated in cases of teeth with an extensively opened floor reaching to the bifurcation. ${ }^{4,27}$

Though pulpectomy is a relatively safe procedure, some serious complications may occur. As the vast majority of dental operations, the adverse events of the local anesthesia are sometimes inevitable. Minor adverse events such as tongue, cheeks, and lips numbness are often minor and resolve spontaneously within few days. However, serious life-threatening allergic reactions up to anaphylaxis may occur. Another relatively common complication of pulpectomy is teeth discoloration resulting from staining of the utilized cement for filling. Excessive hemorrhage at the procedure site may also evolve particularly among patients with history of bleeding diathesis. Local infection may also occur, and pain may result either from spread of this infection or from excessive removal of the necrotic tissue leading to irritation of the adjacent soft tissue. Finally, tooth fracture may occur during the procedure resulting in potential tooth loss. ${ }^{28,29}$

\section{CONCLUSION}

Both pulpotomy and pulpectomy are effective dental therapies to keep the integrity of the teeth pulp. Pulpotomy is usually indicated in patients with vital teeth, whereas pulpectomy is preferred in cases with nonvital teeth. Pulpotomy is suitable for teeth where only the coronal portion of pulp is involved with the caries whist pulpectomy can be used when both the coronal and radicular portions are affected. The presence of local infection, abscesses, or fistula is a contraindication for pulpotomy, and pulpectomy is the therapy of option in these cases. Though both pulpotomy and pulpectomy are safe procedures, some complications are often inevitable such as anaesthesia-related adverse events, tooth infection, tooth discoloration, tooth fraction, excessive bleeding, and persistent pain.

\section{Funding: No funding sources \\ Conflict of interest: None declared \\ Ethical approval: Not required}

\section{REFERENCES}

1. Dentistry TAA of P. The Handbook of Pediatric Dentistry; 2003. doi:10.1002/ejoc.201200111

2. Casamassimo PS, Fields Jr HW, McTigue DJ, Nowak A. Pediatric Dentistry: Infancy through Adolescence; 2013. doi:10.1038/sj.bdj.2013.579

3. Brega H, Seale NS, Alton GM, Carolyn K, Kent BB, Donna L. Pulpotomy versus pulpectomy for carious vital primary incisors: randomized controlled trial. Pediatr Dent. 2012;34(5):112-9.

4. Aapd. Guideline on Pulp Therapy for Primary and Immature Permanent Teeth. Pediatr Dent. 2015.

5. American Academy of Pediatric Dentistry Clinical Practice Guidelines 245.

6. Rosenberg P. Clinical strategies for managing endodontic pain. Endod Top. 2002.

7. Zanini M, Hennequin M, Cousson PY. A Review of Criteria for the Evaluation of Pulpotomy Outcomes in Mature Permanent Teeth. J Endod. 2016.

8. Gesi A, Bergenholtz G. Pulpectomy - studies on outcome. Endod Top. 2003.

9. Nedley MP. The pulpectomy in primary teeth. J Mich Dent Assoc. 2002.

10. Smaïl-Faugeron V, Glenny AM, Courson F, Durieux P, Muller-Bolla M, Fron Chabouis H. Pulp treatment for extensive decay in primary teeth. Cochrane Database Syst Rev. 2018.

11. Aly Ahmed H. Pulpectomy procedures in primary molar teeth. Eur J Gen Dent. 2014;3:3-10. 
12. Bawazir Bds OA. Pulpectomy Technique For Primary Teeth. 2003;23:1.

13. Hasselgren G, Reit C. Emergency pulpotomy: Pain relieving effect with and without the use of sedative dressings. J Endod. 1989;2399(89):80219-5.

14. Markovic D, Zivojinovic V, Vucetic M. Evaluation of three pulpotomy medicaments in primary teeth. Eur J Paediatr Dent. 2005.

15. Fong $\mathrm{CD}$, Davis MJ. Partial pulpotomy for immature permanent teeth, its present and future. Pediatr Dent. 2002.

16. Heinrich-Weltzien R, Kï ${ }^{1 / 2 h n i s c h ~ J . ~ E n d o d o n t i c ~}$ treatment procedures in the primary dentition Actual perspective and clinical consequences. Oralprophylaxe und Kinderzahnheilkd. 2016.

17. Winters J, Cameron AC, Widmer RP. Pulp therapy for primary and immature permanent teeth. In: Handbook of Pediatric Dentistry: Fourth Edition. 2013.

18. Eghbal MJ, Asgary S, Baglue RA, Parirokh M, Ghoddusi J. MTA pulpotomy of human permanent molars with irreversible pulpitis. Aust Endod J. 2009.

19. Ranly DM, Garcia-Godoy F. Current and potential pulp therapies for primary and young permanent teeth. J Dent. 2000;28(3):153-61.

20. Gudkina J, Mindere A, Locane G, Brinkmane A. Review of the success of pulp exposure treatment of cariously and traumatically exposed pulps in immature permanent incisors and molars. Stomatologija. 2012;14(3):71-80.

21. American Academy of Pediatric Dentistry. Guideline on Restorative Dentistry; 2015.

22. McDonald. Dentistry for the Child \& Adolescent.; 2004.
23. Kukreja P, Ravindranath Reddy P, Hugar SM, Shigli A, Hugar SS. Comparative Evaluation of Efficiency of Three Obturation Techniques for Primary Incisors- An In Vivo Study. Int J Oral Heal Med Res Int J Oral Heal Med Res. 2015;2(2)17-8.

24. Evidence-Based Review of Clinical Studies on Pulpectomy. J Endod. 2009;35(8):1121-2.

25. Bergenholtz G, Axelsson S, Davidson T, Frisk F, Hakeberg M, Kvist T, et al. Treatment of pulps in teeth affected by deep caries - A systematic review of the literature. Singapore Dent J. 2013;34(1):1-12.

26. Sahebalam R, Sarraf A, Jafarzadeh H, JouybariMoghaddam M, Seyed-Musavi S. Clinical and Radiographic Success of Electrosurgical Pulpectomy in Primary Teeth. Bull Tokyo Dent Coll. 2017;58(2):77-83.

27. Committee O, Council R. Guideline on pediatric restorative dentistry. Pediatr Dent. 2012.

28. Hülsmann M, Hahn W. Complications during root canal irrigation - Literature review and case reports. Int Endod J. 2000.

29. Marciano MA, Ordinola-Zapata R, Cunha TV, Duarte MA, Cavenago BC, Garcia RB, et al. Analysis of four gutta-percha techniques used to fill mesial root canals of mandibular molars. Int Endod J. 2011;44(4):321-9.

Cite this article as: Baik SA, Mkenah AA, Khan A, Alkhalifah A, Makinah AA, Alquraini H, et al. Pulpotomy vs pulpectomy techniques, indications and complications. Int J Community Med Public Health 2018;5:4975-8. 